\title{
DETERMINANTS OF ECONOMIC GROWTH IN UZBEKISTAN: INTERDEPENDENCE BETWEEN DEVELOPMENT OF FINANCIAL SYSTEM AND ECONOMIC GROWTH
}

\author{
Ulugbek Atamuratov, Graduate School of Economics, Ritsumeikan University, Japan \\ Hiroshi Izawa, Graduate School of Economics, Ritsumeikan University, Japan
}

dx.doi.org/10.18374/JIFE-21-1.3

\begin{abstract}
The importance of the financial system in economic development has long been at the midpoint of policy debate since the early influential paper by Schumpeter J. (1911). Although no unequivocal conclusion has been reached, the majority of academicians and researchers argue that the financial system serves an essential role in economic growth. In addition to this, the corporate governance in financial system has become an important determinant for economic growth since financial system is the locomotive of economy in most developing countries, like Uzbekistan. Moreover, corporate governance is recognized as a modern driver for economic growth (Babic, 2003). In Uzbekistan, banking system and stock market are integral parts of the financial system, so their well-being is an imperative constituent for domestic economy. Indeed, the development of both banking system and stock market strongly impacts on economic growth (Beck T., Levine R., 2004). However, stock market is not yet well developed, so that banking industry plays a predominant role in corporate finance in Uzbekistan (Mizuno M., 2009). Therefore, the whole economy is significantly affected by a slightly changes in the performance and stability of the banking system in Uzbekistan. Furthermore, an economy with a sound banking system is better able to withstand negative shocks and contribute to the stability of the financial system (Athanasoglou P.P et al., 2008). For this reason, well-organized banking system with effective corporate governance practices is very crucial for economic development in a country, particularly in Uzbekistan. Unfortunately, there is an absence of related academic research, especially empirical studies in the area of financial system development - economic growth linkage from corporate governance perspective in Uzbekistan. For this purpose, this study focuses on examining the effect of financial system development on economic growth with considering the corporate governance practices in the context of Uzbekistan over the period of 2003-2018. To carry out our time-series analysis, Vector Autoregression Model (VAR) and Vector Error Correction Model (VECM) are used to measure the interdependence between the development of financial system and economic growth in the short run and in the long run respectively. The main finding is that financial system development has been confirmed as a key determinant for economic growth in Uzbekistan over the period of 2003-2018. More specifically, in the short run there is bi-directional causality from stock market development to economic growth and vice versa while there is unidirectional causality from the development of banking system, on average, ceteris paribus. More interestingly, banking system has substitution effect while stock market has a complementary effect on GDP growth. In addition, in the long run banking system and stock market have asymmetric effects on GDP growth, on average, ceteris paribus. This also confirms that banking system and stock market are substitute to each other in the processes of economic development in the long run. Overall, it can be concluded that financial system development with effective corporate governance practices is very crucial towards further economic development since the development of banking system and stock market have a strong causal relationship with economic growth in Uzbekistan.
\end{abstract}

Keywords: financial system, economic growth, corporate governance, banking sector, stock market, Uzbekistan 